\title{
ENERGY RECOVERY FROM MUNICIPAL SOLID WASTE: OPPORTUNITIES AND CHALLENGES IN THE BRAZILIAN SCENARIO
}

\author{
Y. L. Pilissão, \\ A. G. Machado,
E. Virmond,
and E. S. Watzko \\ A. G. Machado,
E. Virmond,
and E. S. Watzko \\ ABSTRACT \\ Municipal solid waste has always been an undesirable asset in society, and \\ its generation grows every year. Inadequate waste disposal may cause many \\ problems, either by the contamination of the environment or by its capacity \\ to serve as a vector for a series of pathogenic elements. The COVID-19 \\ pandemic drew the world's attention to these challenges and made it clear \\ how they impact society in an unprecedented way. The higher amount of \\ Federal University of Santa Catarina Campus \\ Araranguá, \\ Graduate Program in Energy and \\ Sustainability, \\ Rua Pedro João Pereira, 150, Mato Alto, \\ Araranguá, Santa Catarina, Brazil. \\ pyurilucian@gmail.com \\ adilsongm@gmail.com \\ elaine.virmond@ufsc.br \\ elise.sommer@ufsc.br \\ Received: Jul 30, 2021 \\ Revised: Aug 23, 2021 \\ Accepted: Aug 25, 2021 \\ waste and safety supplies discarded, such as masks and facial shields, \\ require an analysis of the current situation of solid waste management along \\ with solutions to increase the capacity for resource recovery. Methods of \\ treating, collecting, transporting, and disposing of municipal solid waste \\ must be integrated with the other levels of the waste hierarchy (prevention, \\ reuse and preparing for reuse, recycling, other recovery (including energy \\ recovery), and disposal). The scientific literature on this subject was \\ verified in this paper, serving as a subsidy for the implementation of \\ possible processes to be used in companies in the area of basic sanitation \\ and city halls, which can benefit from investments that will incur in the \\ generation of products of added value, creating a new link in its business \\ chain. The production and application of integrated municipal solid waste \\ management systems, including energy recovery from refuse derived fuel, \\ can reduce the volume and expenses of municipal administrations with \\ inadequate waste disposal in landfills and promote more sustainable \\ practices in the circular economy scenario. Therefore, this paper sought to \\ highlight the main activities related to municipal solid waste management \\ with an aim to energy recovery. \\ Keywords: waste-to-energy, circular economy, refuse derived fuel, \\ resource recovery.
}

\section{NOMENCLATURE}

ABRELPE (Brazilian Association of Public Cleaning and Special Waste Companies);

ABREN (Brazilian Association for Energy Recovery of Waste);

ANCAT (National Association of Waste Pickers and Recyclers);

GHG (Greenhouse gas)

LHV (Lower Heating Value);

MSW (Municipal Solid Waste);

RDF (Refuse Derived Fuel);

SDG (Sustainable Development Goals);

WtE (Waste-to-Energy).

\section{INTRODUCTION}

Historically, solid waste has always been an undesirable result of most human activities, and several factors, such as population growth, globalization, urbanization, among others, have increased the quantity and diversity of solid waste generated (CHEN et al., 2010). The outbreak of COVID-19 shows the size of the challenge the world faces, keeping a dramatic situation in check. Estimates show that, during the health emergency period resulting from the COVID-19 pandemic, and due to the quarantine, isolation, and social distance measures adopted, there has been a significant increase in the amount of solid household waste generated in Brazil, from $15 \%$ to $25 \%$. (ABRELPE, 2020). Because of this essential aspect, proper management of Municipal Solid Waste (MSW) is, collectively with health care and sanitation services (such as water and sewage treatment), one of the main sanitary barriers against the transmission of Coronavirus. According to Abrelpe (2019), the generation of MSW in Brazil reached 216,629 tons per day. This means that, on average, each Brazilian generated over 1 kilogram of waste per day, with a total generation of 79 million tons of MSW in 2019. The final destination given for the majority of the waste today is landfilling, which received $59 \%$ of the municipal solid waste collected in Brazil (43.3 million tons). The rest of it (40\%) was discarded in inappropriate places, that is, 30 million tons of MSW ended up going to controlled dumps or landfills which do not have a set of systems and measures 
necessary to protect people's health and the environment (ABRELPE, 2019). Only 3.9\% were recycled and destined for composting (ANCAT, 2019). In the state of Santa Catarina (2018) 1,752,830 tons of MSW were collected, $93.9 \%$ derived from the conventional collection and $6.1 \%$ from the selective collection. Considering the amount and the service rates of conventional and selective collection services, the average per capita production was 0.85 $\mathrm{kg} / \mathrm{person} /$ day in this state (BRASIL, 2019). Only $6.44 \%$ of the municipalities of Santa Catarina apply composting as a treatment for the organic fraction of MSW, and at least $68.47 \%$ have their MSW sent to recycling sorting units. As final destination, currently, 34 landfills receive MSW from 295 municipalities in the state (SANTA CATARINA, 2018). Santa Catarina stands out on the national scene in the treatment of MSW, pioneering the closure of dumps in 2014.

The practice of disposing of waste to landfills (which is currently dominant in Brazil) represents a high financial cost for municipalities. In 2018, Brazilian cities invested, on average, US\$ 2,00 per month (exchange rate date: December 18, 2020), per person to perform urban cleaning services. The urban cleaning market moved resources corresponding to US\$ 5.5 billion in the country that same year (ABRELPE, 2019). In response to such problems, several countries have developed methods and technologies to deal with solid waste management. The ideas range from reduction through product and packaging design, to recycling materials that can be reused by industry and commerce, as well as the composting of organic material and heat treatment with energy recovery, known as Waste-to-Energy (WtE) plants (TISI, 2019). Studies by the Earth Engineering Center point out $\mathrm{WtE}$ as the best waste management route, concluding that the energy recovery plants are superior to other alternatives available for MSW treatment when taking into account the waste hierarchy, and is considered a complement to recycling (THEMELIS et al. 2016).

The recently approved Brazilian Law 14,026, of July 15, 2020 (BRASIL 2020) updated the legal framework for basic sanitation in Brazil, as well as the deadlines of the National Solid Waste Policy PNRS, Law 12,305 of August 2, 2010 (BRASIL, 2010) for environmentally appropriate final disposal of waste. According to the National Solid Waste Plan (BRASIL, 2020), the intention is to eliminate the final disposal of MSW in controlled dumps and landfills by the year 2024. Law 513, of March 4, 2020 (BRASIL, 2020b), provides incentives to companies and thermal treatment of tailings aiming at energy recovery. The Inter-Ministerial Ordinance, 274, of April 30, 2019 (BRASIL, 2019c) regulates the energy recovery of MSW and classifies the Energy Recovery Plant as any unit dedicated to the thermal treatment and recovery of thermal energy generated by combustion, or power generation.
Turning waste into energy can be one key to a circular economy enabling the value of products, materials, and resources to be maintained on the market for as long as possible, minimizing waste and resource use and leaving aside the old-fashioned disposal of waste to a more intelligent waste treatment encompassing the circular economy and energy recovery (MALINAYSKAIATE, 2017).

Given the particularities of MSW, in-depth studies are required for the development and optimization of collection and treatment logistics, subsequent application in energy recovery processes. Based on the identification of such problems, this research to establish a current scenario for the energy recovery, which is an environmentally suitable way to dispose of municipal solid waste.

\section{WASTE MANAGEMENT AND ENERGY RECOVERY}

\section{Basic sanitation and the pandemic crisis}

According to Nouvion (2020), providing urban cleaning and sanitation services is essential for protecting the environment and human health and cannot be interrupted, even during epidemic processes. The current economic development and population growth have promoted an increasing generation of MSW worldwide, and its management has become challenging in social, economic, and environmental terms. It is estimated that by 2025 the quantity of MSW produced in the world will increase to 2.2 billion tons per year (INFIESTA et al., 2019). According to a study by the International Solid Waste Association (ISWA, 2015), Brazil spends approximately US\$296 million (exchange rate date: December 18, 2020) per year in the treatment of diseases of people who have had inadequate contact with MSW, that is, US\$ 2 billion in ten years. In this context, it should be considered new approaches for treating MSW, bringing a better destination, and final elimination for materials that are a potential harm to human health and that are currently vectors of several diseases.

\section{Integrated and sustainable waste management}

Integrated sustainable waste management is an integral part of sustainable development and has become increasingly important on the Sustainable Development Goals (SDG) agenda. When dealing with MSW management, it is relevant to clarify the concepts of waste and management initially. According to the Brazilian Association of Technical Standards (ABNT NBR 10.004, 2004), it is considered solid waste those wastes in solid and semi-solid states, which result from activities of the community of origin: industrial, domestic, commercial, agriculture, services and sweeping. Still, according to such normative, waste can be divided 
into three groups based on its potential for damage to health and the environment, which are:

- Class I - (hazardous): waste that presents a risk to public health or the environment, whose inherent characteristics have properties of flammability, corrosivity, reactivity, toxicity, or pathogenicity;

- Class IIA - (non-hazardous and non-inert): residues that do not have the properties of flammability, corrosivity, reactivity, toxicity, or pathogenicity. However, they have the property of solubility in water (above the standards established by the ABNT standard), with the possibility of a reaction with the environment, and, consequently, risk of pollution;

- Class IIB - (non-dangerous and inert): those that do not have any constituent solubilized in a higher concentration than the water potability standard.

Therefore, MSW, is defined as solid waste from cities, which is composed of two fractions: organic (wet) and inorganic (dry). The inorganic fraction is composed of solid materials, such as plastic, glass, rubber, paper, metals. These are subdivided into two factors, (i) recyclable and (ii) inorganic waste, although almost all of it is liable to be processed and recycled. However, the expense of recycling tends to create a limiter in this process (ABNT, 1996).

The PNRS defines the management of MSW and refers that it was created to guarantee the greatest reintegration of wastes into the production systems, promoting the order of priorities from nongeneration, reduction, reuse, recycling, treatment, and environmentally appropriate final disposal of waste (BRASIL, 2010). This order of priorities is seen in the European Commission's Report, "The Role of Waste-to-energy in the Circular Economy", released in 2017 in Brussels as essential. The report also points out alternatives for final disposal (COM, 2017). According to the document, the waste management hierarchy is a vital element of the European Union's waste policy and legislation, and a key to the transition for a circular economy. Its main goal is to establish an order of priority that minimizes adverse environmental effects and optimizes resource efficiency in waste prevention and management. The report also argues that an influence of the waste hierarchy from a climactic point of view occurs, in which landfill disposal is generally the least favorable option for reducing greenhouse gas (GHG) emissions. On the other hand, waste prevention, reuse, and recycling have outstanding potential to reduce GHG emissions (COM, 2017). Figure 1 shows the waste management hierarchy and its order of priority for its treatment.

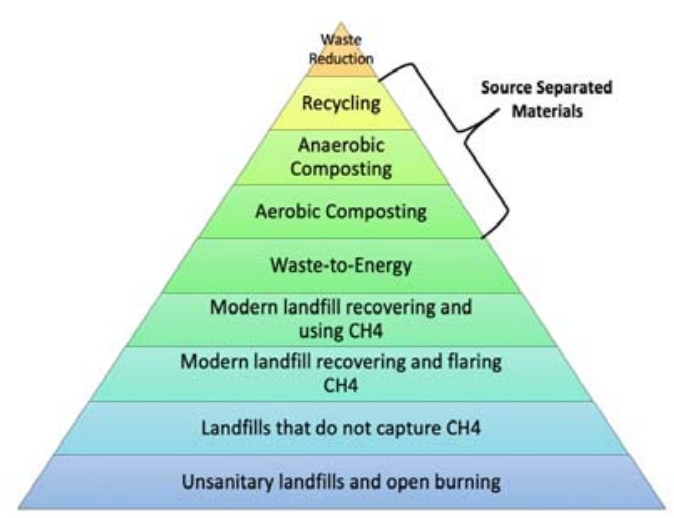

Figure 1: Waste management hierarchy. Adapted from Themelis (2019)

The prevention and reduction of waste should be the priority of waste management. Reuse, recycling, and composting of materials should have priority over the energy recovery of waste. These are necessary steps so that only the refused waste is used in the heat treatment step in WtE systems. It is estimated that allocating $35 \%$ of MSW to energy recovery plants would be interesting for Brazil and that by 2031 US\$ 2,1 billion (exchange rate date: December 18, 2020) will be needed in infrastructure investments to guarantee the universality of sustainable solid waste management in the country, in the activities of recycling, bio-digestion, thermal treatment of MSW, co-processing plants for the manufacture of cement with Refuse Derived Fuel (RDF), pyrolysis of a tire and other synthetic materials, among other technologies for energy recovery (VIEIRA, 2019).

The choice of treatment technologies plays an important role in meeting the various criteria of MSW management, being largely determinant of the success or failure of the respective management system. No waste treatment technology fits perfectly in all areas and for all types of waste. An accurate study of the materials that make up the waste and its calorific value must be carried out (TISI, 2019).

\section{Characterization of municipal solid waste}

According to Lagerkvist and Dahlén (2012), the waste category MSW consists predominantly of household waste. It is a generic term including several different types of consumption wastes originating from activities in private homes. As reported by these authors, other wastes are under municipal responsibility, such as street sweepings, waste from public institutions, litter collected in public litter bins, and green waste from tending public parks. Depending on the aspects of the region (coastal and touristic) or local culture, seasonal variations in the quantity and variety of MSW may occur. The developing economy and the pace of 
production and consumption of goods consequently reflect in waste generation. All products and materials introduced into society will end up somewhere (LAGERKVIST; DAHLÉN, 2012). The MSW characterization process is an important basis for the analysis of waste management systems, and essential to determine its capacity as a fuel or use in co-combustion. Waste characterization is a term that is broadly used to denominate the actions undertaken to learn about the intrinsic properties of a waste and how these properties affect the environment where the material is, and how the environment affects the material (LAGERKVIST; DAHLÉN, 2012). A common method for household waste component studies is manual sorting of waste samples, where the results are presented as the weight percentage of different materials found in the waste samples. The main stages of preparation and characterization of the material are based on techniques used for other fuels. Soares (2011) used the characterization of MSW according to the definition of the Brazilian standard ABNT NBR-10.004 (ABNT, 2004), considering the following criteria: the amount of waste received (ton/day); waste class; the origin of the waste; type of supply; the estimate of homogeneity and gravimetric of waste.

The average gravimetric composition of MSW collected in Brazil, according to a report by ABRELPE, is based on more than 186 Brazilian cities, with a minimal categorization of organics, metal, glass, plastic, paper, cardboard, and rejects. In the panorama of solid waste published (ABRELPE, 2020), the organic fraction still remains the main component of MSW, with $45.3 \%$. Dry recyclable waste totals $33.6 \%$, being mainly composed of plastics $(16.8 \%)$, paper and cardboard $(10.4 \%)$, in addition to glass $(2.7 \%)$, metals $(2.3 \%)$, and multilayer packaging $(1.4 \%)$. The tailings, in turn, correspond to $14.1 \%$ of the total and include mainly sanitary materials. Other fractions include textile residues, leather, and rubbers, totalling $5.6 \%$, besides other residues $(1.4 \%)$, which include various materials that are theoretically objects of reverse logistics (ABRELPE, 2020).

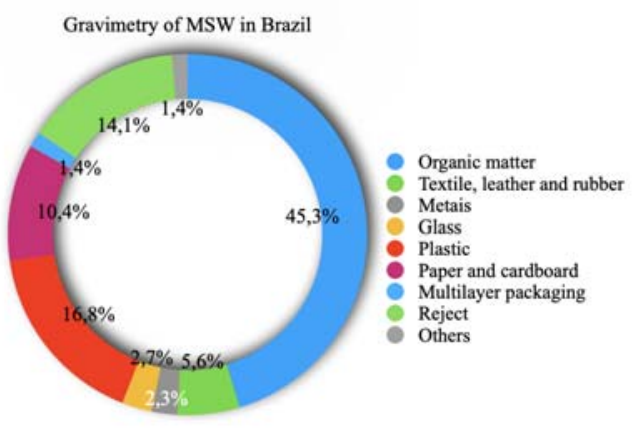

Figure 2: Gravimetric composition of MSW in Brazil. Adapted from ABRELPE (2020)
The use of this fuel is already a reality in several countries, and the potential of this material as a fuel in several industry sectors has already been verified. The analysis techniques and standards implemented are much more developed in these countries (Kyprianidis and Skvaril, 2016). Thus, it is possible to use new specific characterization standards for this type of material.

Soares (2011) applied a classification of the MSW obtained after splitting about $100 \mathrm{~kg}$ of product. For this, the MSW is spread to be separated into the following fractions: paper / cardboard; Rigid Plastic; soft plastic; organic matter (food waste and vegetable leaves); rubber; leather; polystyrene; Wood; rags; metals; glass; diapers; foam; others. After the separation, the materials are weighed and then go through a drying process to determine the free moisture. The final step is grinding to reduce the average particle size of the material followed by homogenization to obtain a characteristic mixture.

Wang et al. (2021) employed multiple linear regression and artificial neural network (ANN) techniques to predict LHV through data-driven models utilizing 151 globally distributed datasets identified during a systematic literature review, describing the wet physical composition of MSW and measured LHV. The results showed that models built via both methods exhibited acceptable and compatible levels of performance in predicting LHV, based on the multiple statistical indicators.

Table 01 - Lower heating value (LHV) of some of the materials found in the MSW

\begin{tabular}{|c|c|}
\hline Material & $\begin{array}{c}\text { Lower heating value } \\
(\mathrm{LHV})^{\mathrm{a}}{ }^{(\mathrm{kcal} / \mathrm{kg})}\end{array}$ \\
\hline Plastic & 6.300 \\
\hline Rubber & 6.780 \\
\hline Leather & 3.630 \\
\hline Textiles & 3.480 \\
\hline Wood & 2.520 \\
\hline Foods & 1.310 \\
\hline Paper & 4.030 \\
\hline
\end{tabular}

According to Themelis et al. (2019), the calorific value of MSW is typically $10 \mathrm{MJ} / \mathrm{kg}$ or 2.8 $\mathrm{MWh} / \mathrm{t}$, although there is a wide variation in this value. Moisture and non-combustible materials (glass and metals) reduce the calorific value of MSW, which can vary from 8 to $14 \mathrm{MJ} / \mathrm{kg}$ (1,912 to 3,350 $\mathrm{kcal} / \mathrm{kg}$ ), with the highest values coming from mixtures of MSW and industrial waste, and the 
lowest, MSW with high moisture content. The efficiency of the MSW energy recovery process is strongly dependent on the lower heating value (LHV) of the materials, meaning the net amount of energy that can be achieved from the waste. Some of the materials present in the MSW have above 6,000 $\mathrm{kcal} / \mathrm{kg}$, matching the values of some fossil fuels (EPE, 2008). Based on its composition, it is possible to estimate the average LHV of MSW.

As reported by the Brazilian Association for the Recovery of Waste Energy (ABREN), assuming an average LHV of $7,500 \mathrm{~kJ} / \mathrm{kg}$, the gross electrical performance of a $28 \%$ energy recovery plant, and the annual availability of 8,000 hours, there is a potential for power generation from MSW of 19 TWh per year. This represents an installed capacity of 2,358 MW in the 28 metropolitan regions of the country (ABREN, 2020).

The electricity generation in Brazil reached 626.3 TWh in 2019, an amount $4.1 \%$ higher than the result for 2018 (EPE, 2020). Therefore, if the MSW from the 28 metropolitan regions and the 35 municipalities were converted into energy instantly in WtE plants, the generation would correspond to about $5 \%$ of the national energy generation, representing marginal participation in the Brazilian electrical matrix, but with a massive impact on the Brazilian sanitation, which is decades behind developed countries (ABREN, 2020).

The MSW has enormous potential for the production of biogas, biomethane, and hydrogen. Abiogás (2019) estimated that the potential for biogas production in Brazil is 82 billion $\mathrm{Nm}^{3} /$ year, 41 billion $\mathrm{Nm}^{3} /$ year from the sugar-energy sector (sugarcane and its derivatives such as bagasse, straw, filter cake, and vinasse), 37 billion $\mathrm{Nm}^{3} /$ year from the agricultural sector (animal protein, animal waste, and corn, cassava and soybean crops) and 3 billion $\mathrm{Nm}^{3} /$ year from the environmental sanitation sector (sanitary sewage sludge and MSW). Thus, the choice of the technological system that best adapts to each region must observe several social, environmental, and economic aspects. The analysis of the waste composition is crucial for determining the viability of energy recovery.

\section{Obtaining fuel derived from waste}

An option for the non-recyclable fraction of MSW is to process it to obtain Refuse Derived Fuel (RDF). Due to its lack of homogeneity, its high moisture content, and a fraction of incombustible, municipal solid residues cannot burn on a large scale unless they are transformed into a more homogeneous raw material (and with a more homogeneous calorific content). Unfortunately, the fuels that may derive from MSW are almost as diverse as MSW themselves (KYPRIANIDIS AND SKVARIL, 2016). Several processes are being implemented to produce RDF from urban waste, and the combination of MSW and biomass is an interesting option concerning the carbon footprint. These processes generally consist of sorting and mechanical separation of waste, size reduction (crushing, chipping, and grinding), separation and sieving, mixing, as well as drying and densification.

A variation of the RDF processing is also used in the European Union, where the MBT process treats mixed MSW and produces RDF that is burned with coal in thermoelectric and cement plants, which need to be equipped with air pollution control with the same performance as those of WtE plants (TISI, 2019). All these steps are necessary to increase the homogeneity and calorific value of the final RDF, improving its handling and feeding when using the unit operations applied for traditional fuels. Figure 3 shows the RDF production.

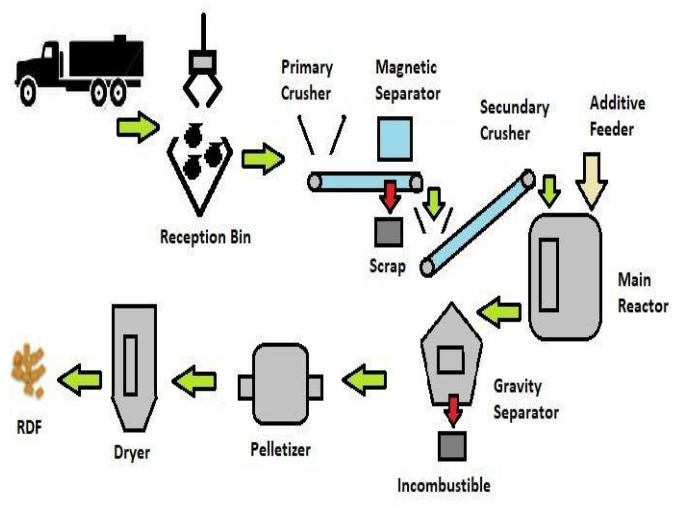

Figure 3: RDF production chain.

Adapted from Kyprianidis and Skvaril (2016)

RDF can be formed through densification, such as pellets or briquettes, which presents advantages over unprocessed materials. Higher energy density, greater thermal regularity (facilitates the operation of conversion systems), ease of logistics transport and storage (lower costs due to the greater mass of fuel per unit volume), cleaner and more homogeneous fuel (regular and uniform composition, which favors greater combustion efficiency).

The RDF and compacted biomass with a high calorific value constitute an unconventional and renewable energy source and could be used to partially reduce the actual dependence on fossil fuels (such as coal) and provide an alternative path for the reuse of such materials. Emissions (dioxins, furans, mercury, cadmium, lead, hydrochloric acid, sulfur dioxide, and particles) related to the burning of alternative fuels derived from solid waste in tests carried out in the USA were lower than the fossil fuel installations (CACCIOLA and SOBKOWICZ, 2015).

These characteristics enhance the innovative participation of fuel derived from MSW and biomass as an alternative and partially renewable fuel for the energy and industrial sector. The densification 
technologies available have been developed for other sectors intended to meet the requirements for RDF specifications for energy industry supply system logistics or as a raw material for a conversion facility (TUMULURU et al., 2011). Depending on the fuel that is replaced, the densified RDF can positively impact the energy industry through efficiency gains and reduced pollutant emissions. The combination of biomass and high-calorific waste offers two main benefits: on the one hand, the maximization of the use of energy sources and, on the other hand, a potential solution for the disposal of plastic waste (GARRIDO et al., 2017).

Studies by Gug and Cacciola (2015) showed that the pellets obtained from the raw materials of MSW and biomass are highly dense and with a low moisture content $(<10 \%)$, which allows for high energy conversion efficiency (around 75\%). Although the briquetting process is a technology used mainly to compact biomass, briquettes made from fuel derived from waste, textiles, or mixtures of plastic waste can also be produced (GARRIDO et al., 2017).

Recent studies reported new experimental procedures based on statistics, which take advantage of the analysis time to decrease the error in determining the interaction of the parameters of the pressing process (IQBAL et al., 2015, TUMULURU, 2011). However, few research papers are reporting this optimization relationship for pellets of mixed biomass and MSW composition, with the analysis of these influences on the quality of the densified product.

\section{Energy recovery as an environmentally appropriate way of treating municipal solid waste}

In Brazil, there is still no thermal waste treatment plant in operation, only a few small experimental plants and some landfill gas capture plants (VIEIRA, 2019). However, methods and technologies to deal with the management and disposal of solid waste have been developed (SONG et al., 2020; VIEIRA, 2019). Themelis et al. (2019) have pointed to the $\mathrm{WtE}$ power plants as an alternative to sanitary landfills, which transform the post-recycling residues of society into electricity, heat, and recyclable metals. According to the author, this is a great example of industrial ecology because it is a way of closing the materials cycle, therefore promoting the circular economy. One can classify the environmental performance of waste management by analyzing the capacity of recovery of materials through recycling, composting and energy conversion (i.e., WtE) with the amount of MSW that is landfilled (THEMELIS et al, 2019). As reported by these authors, cities and countries strive to increase their recycling and composting rates as much as possible. A very successful example is the European Union that has directed its member nations to phase out landfilling by increasing their recycling and $\mathrm{WtE}$ capacities. The progress made between 1995 and 2015 in reducing the European landfilling rate to $25.3 \%$. This was due to the increase in recycling plus composting rates to $46.3 \%$, and the $\mathrm{WtE}$ rate to 28.4\% (THEMELIS et al. 2019).

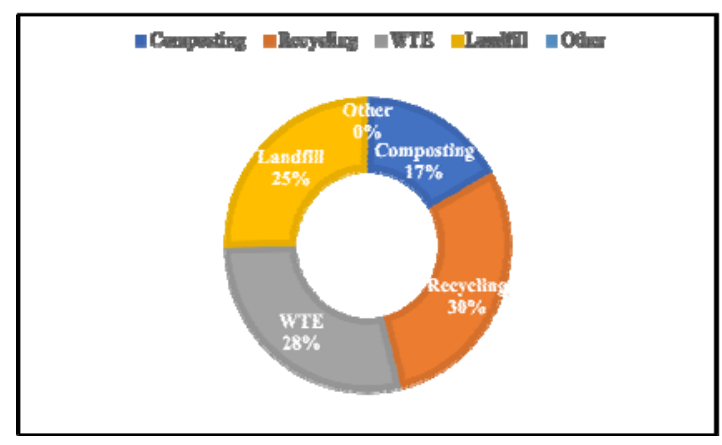

Figure 4: Management of MSW in EU in 2015. Adapted from THEMELIS (2019)

Energy recovery requires several methods and processes, which can be divided into three groups: mass burning incineration, which operates with excess oxygen; gasification and pyrolysis, which operate with oxygen deficit; physicochemical conversion and biochemical conversion (SOMPLAK, 2014; BING, 2016; MALINAUSKAITE, 2017; THEMELIS and BOURTSALAS, 2019; TISI, 2019; VIEIRA, 2019). The available technologies can be seen in Figure 5.

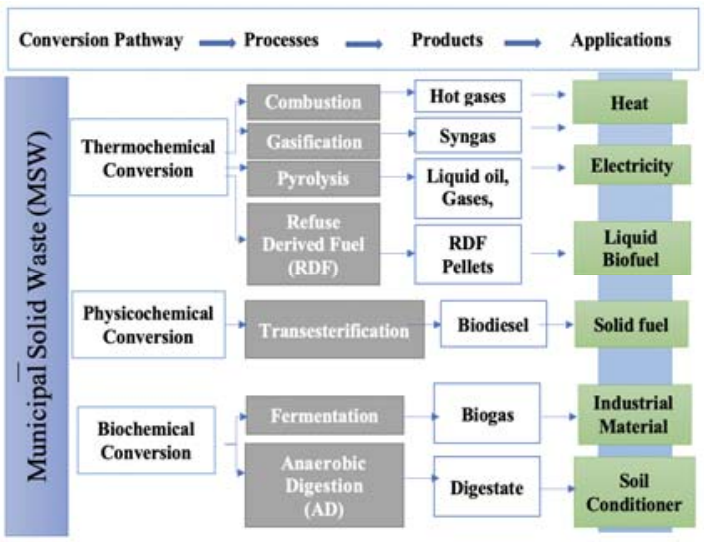

Figure 5: Waste energy recovery technologies. Adapted from MALINAUSKAITE (2017)

The most common treatment method is incineration followed by pyrolysis and gasification (Tozlu et al. 2016). According to Chen et al. (2020), current $\mathrm{WtE}$ plants are generally characterized by low efficiency (ranging from $18 \%$ to $25 \%$ in most cases), especially compared to conventional steam plants using fossil fuels. Several studies have been done on the incorporation of a $\mathrm{WtE}$ system into another 
thermal system. Consonni (2007) and Poma (2010) explored the hybrid project containing a WtE system and a combined cycle using natural gas, where the saturated steam produced in the $\mathrm{WtE}$ boiler is exported to the combined cycle heat recovery steam generator to be superheated and then powered by a steam turbine serving both the combined cycle and the WtE system.

For Perrot and Subiantoro (2018), the most mature technology is mass-burning incineration, which can generate 400-700 kWh per ton of MSW. Integrated gas turbines and $\mathrm{WtE}$ plants have recently been proposed to increase energy efficiency by more than $40 \%$. Although the technology is not yet mature, the integrated system is promising. An example is the WEG Solution developed for the generation of electric energy from MSW gasification. Several steps transform MSW into fuel gas which, when burned, generates heat in a boiler, and the steam can be used to drive a turbine to produce electricity. The process allows full use of the calorific power of the waste, reducing the generation of environmental liabilities (WEG, 2019).

Pyrolysis can be defined as the thermal degradation of organic material in the absence of oxygen producing gas, liquid and solid products (Sipra et al., 2018). An ideal pyrolytic process for MSW should be able to handle the MSW with timevarying compositions and moisture content and generate end products in response to the market needs, subjected to maximal energy recovery and minimal carbon footprint criteria (Lee, et al., 2020). The constituents of MSW can yield various intermediates in a pyrolytic environment, and these may interact with each other, causing synergistic pyrolysis (Chhabra et al., 2019). Synergistic pyrolysis, if it occurred, would accelerate the rate of the pyrolytic reactions and/or shift the end products of the MSW pyrolysis to favor the formation of more value-added products (Lu, et al., 2020). Over $40 \%$ of recent studies of the pyrolysis of MSW used thermogravimetric analysis (TGA), probably because of its versatility and ability to scan a range of temperatures in a single test. Most studies involve temperatures in a typical range from the ambient temperature to $900{ }^{\circ} \mathrm{C}$ ( $\mathrm{Lu}$, et al., 2020). TGA tests are particularly useful for screening potential feedstocks that are obtained from many possible substrates/experimental conditions of interest. The major end-products of the slow pyrolysis of organic feedstocks include syngas, pyrolysis oil, and bio-char (Lu, et al., 2020).

$\mathrm{Lu}$, et al. (2020) used the copyrolysis of these solids to produce a solid carbonaceous product (coal) and a mixture of gases, burned in a post-combustion chamber to generate heat. The synergistic effects of copyrolysis of food residues with other constituents on the reaction rates and distribution of the final product are significant. They are generally welcome as they improve the quality of the pyrolysis oils produced (Lu, et al., 2020). The process in separate pyrolysis and combustion steps minimized emissions of chlorine, BTEX, dioxins, furans, $\mathrm{SO} 2$, and $\mathrm{NOx}$, which were below legal limits in several countries. This was achieved by controlling the operational parameters, such as the temperature of the pyrolysis chamber and the excess air in the combustion chamber. It was concluded that the pyrolysis process coupled to the post-combustion can be advantageous, being necessary for the preliminary analysis of the fuel.

The heterogeneity of MSW plays a vital role in determining the product's yield (Sipra et al., 2018). From the pyrolysis of RDF and biomass, it is possible to obtain hydrocarbons with characteristics like commercial liquid fuels such as gasoline and diesel (LORA and VENTURINI, 2012), and such process can also generate a carbonaceous solid material, a fuel with great demand in the Brazilian industrial sector (eg., for steel and cement production). From the pyrolysis of RDF and biomass, it is possible to obtain hydrocarbons with characteristics like commercial liquid fuels such as gasoline and diesel (LORA and VENTURINI, 2012), and such process can also generate a carbonaceous solid material, a fuel with great demand in the Brazilian industrial sector (eg., for steel and cement production).

Silva Filho (2019), presented a new Brazilian system on a pilot-scale that combines the processes of pyrolysis and combustion, powered by a mixture of MSW and wood chips. The co-pyrolysis of these solids produced a solid carbonaceous product (coal) and a gas mixture, burned in a post-combustion chamber for heat generation. The process in separate pyrolysis and combustion steps minimized emissions of chlorine, BTEX, dioxins, furans, $\mathrm{SO}_{2}$, and $\mathrm{NO}_{\mathrm{x}}$, which were below legal limits in several countries. This was achieved by controlling the operational parameters, such as the temperature of the pyrolysis chamber and the excess air in the combustion chamber. It was concluded that the pyrolysis process coupled to the post-combustion can be advantageous, being necessary for the preliminary analysis of the fuel.

\section{Application of fuel derived from waste}

Once produced, fuel derived from waste can be useful for electricity production (isolated or combined with coal or natural gas in thermoelectric plants or cogeneration plants); energy source in industrial processes, such as cement kilns and blast furnaces; constitution of new materials, for example, in the production of asphalt or construction materials (KYPRIANIDIS AND SKVARIL, 2016; ERFO, 2020). These uses may result in more efficient applications of the calorific value of the waste and in a significant reduction in the $\mathrm{CO} 2$ emitted due to the substitution of fossil fuels, such as coal and lignite. 
During co-combustion studies, the proportions of each fuel are expressed in terms of a weight fraction or energy fraction (also called thermal). The use of this type of fuel, however, requires a stable supply of pre-treated and homogenized waste, with a quality of fuel that can be traded between producers and users. Of the various technical standards developed by the European Union to meet this requirement, EN 15359 (GARCÉS; DÍAZ; SASTRE; ORDÓÑEZ; GONZÁLEZ-LAFUENTE., 2015) is one of the most important. This standard provides a specification and classification system for the RDF (GARCÉS; DÍAZ; SASTRE; ORDÓÑEZ; GONZÁLEZ-LAFUENTE., 2015). As a general rule, fuel derived from waste should not be used if the thermal energy produced in combustion is less than the energy used to process the fuel (there must be an energy gain) (ZKG, 2014). According to ERFO (2020), other points that should be noted concerning the use of solid waste as fuel, as a way to avoid waste and increase sustainability in the production chain, are:

- the substance must be commonly used for specific purposes; a market or demand must exist in the region;

- the substance meets the technical requirements for specific purposes and complies with existing legislation and standards applicable to products;

- the use of the substance will not lead to general adverse environmental impacts or human health.

A variation of RDF processing is also used in the European Union, where the MBT process treats mixed MSW and produces RDF that is burned with coal in thermoelectric and cement plants, which need to be equipped with air pollution control with the same performance as those from $\mathrm{WtE}$ plants (TISI, 2019).

\section{Contributions from the use of fuel derived from densifild waste}

There are benefits in the social, economic, and environmental spheres by developing alternative treatments for MSW landfills, integrated with solid waste management hierarchy (reduce, reuse, recycle, recover). The production and energetic application of fuel derived from MSW can reduce the volume and expenses of municipal administrations and optimize the operation of those who have their income derived from the disposal of MSW. These will change from deposits of raw MSW to processing units that obtain compacted fuel derived from MSW (pellets or briquettes) and derived products since it can be directly marketed or converted in a thermal system installed in the place where it is produced. Promoting more sustainable practices in the management of MSW stimulates an increasing coverage of the collection and treatment in the country, and it may make the operation more technically, economically, and environmentally viable, thus contributing to making basic sanitation more sustainable.

\section{CONCLUSIONS}

International experience (European Union, United States, China, India, among others) indicates that solid waste can be used in energy production. As the GHG effects, the contamination due to landfills and the non-renewable energy resources are critical for human health, there should be an approach for meeting the needs of increasing energy on a global scale. Therefore, planning the transition for sustainable energy recovery is essential.

These countries included energy recovery as a priority in waste treatment, which resulted in a sustainable destination for solid waste and also contributed to the generation of clean, renewable, attributing reliability and stability to the electrical system. Based on all the assumptions presented, it becomes relevant that public policy mechanisms are put in place to promote implementing waste energy recovery in Brazil. The adoption of integrated sustainable waste management, the changes in the PNRS, and the approval of the basic sanitation legal framework bring together other regulations, legal incentives, and regulatory procedures for the energy recovery of waste. The MSW energy harnessing actions are excellent alternatives for both the basic sanitation management process and energy production. This alternative could evolve into a new production chain within the MSW area, adding value to the production chain and generating jobs and income. It changes from a conservative idea of garbage storage to noble use in the generation of energy.

\section{ACKNOWLEDGEMENTS}

The authors are grateful to the Coordination for the Improvement of Higher Education Personnel (CAPES/Brazil).

\section{REFERENCES}

ABNT. Associação Brasileira de Normas Técnicas. Norma Brasileira ${ }^{\circ}$ NBR 10.004, de 31 de maio de 2004. Resíduos Sólidos - Classificação. Rio de Janeiro, RJ.

ABNT. Associação Brasileira de Normas Técnicas. ABNT NBR 8419:1992: Apresentação de projetos de aterros sanitários de resíduos sólidos urbanos. 3 ed. Rio de Janeiro: Abnt, 1996. 7 p.

ABRELPE (São Paulo). Associação Brasileira de Empresas de Limpeza Pública. Recomendações para a gestão de resíduos sólidos durante a Pandemia de Coronavírus (COVID-19). São Paulo, 2020. 5 p. Available in: https://abrelpe.org.br/abrelpe-nocombate-a-covid-19/. Access in: 07 set. 2020. 
ABRELPE (Brasil). PANORAMA DOS RESÍDUOS SÓLIDOS NO BRASIL 2018/2019: abrelpe. 15. ed. São Paulo, 2019. 64 p. Available in: www.abrelpe.org.br. Access in: 17 jul. 2020.

ABIOGÁS (São Paulo). Brazilian Biogas Association. Proposta de Programa Nacional do Biogás e do Biometano. 19. ed. São Paulo, 2019. 177 p. Disponível em: https://abiogas.org.br/en/. Access in: 22 dez. 2020.

ANCAT (São Paulo). Associação Nacional dos Catadores e Catadoras de Materiais Recicláveis (org.). Anuário da Reciclagem 2017-2018. São Paulo: Pragma Soluções Sustentáveis, 2018. 56 p. Disponível em: https://ancat.org.br. Access in: 17 set. 2020.

AUPRAKUL, Unchana. Factors affecting properties of fuel pellets from compaction of mixed biomass and waste plastics Agric EngInt: CIGR Journal Open access at http://www.cigrjournal.org Vol. 21, No. 3 123. 2019.

Batistella, L.; Silva, V.; Suzin, R. C.;Virmond, E. ; Althoff, C. A.; Moreira, R.F.P.M.; José, H. J. Gaseous Emissions From Sewage Sludge Combustion In A Moving Bed Combustor. Waste Management, [S.L.], v. 46, p. 430-439, dez. 2015. Elsevier BV

http://dx.doi.org/10.1016/j.wasman.2015.08.039.

BRUSSELS. European commission. (org.). Communication from the commission to the european parliament, the council, the european economic and social committee and the committee of the regions: the role of waste-to-energy in the circular economy. Brussels, 2017. 11 p. Available in https://ec.europa.eu/environment/waste/waste-toenergy.pdf. Access in: 17 jul. 2020.

Barbosa et al. Caracterização do resíduo de MDF e seu aproveitamento na produção de pellets. Nativa, Sinop, v. 6, n. 3, p. 300-304, mai.jun. 2018. Available in: https://core.ac.uk/download/pdf/ 229928717.pdf. Access in 29 ago. 2020.

Besen, G.R.; fracalanza, A.P. Challenges for the Sustainable Management of Municipal Solid Waste in Brazil. DISP, 2016.

BRASIL, Lei 12.305 de 2 de agosto de 2010 , Institui a Política Nacional de Resíduos Sólidos; altera a Lei no 9.605, de 12 de fevereiro de 1998; e dá outras providências. Brasília, DF: Presidência da República, $2010 . \quad$ Available in:http://www2.mma.gov.br/port/conama/legiabre.cf m?codlegi=636. Access in: 13 abr. 2020.

BRASIL, Ministério do Meio Ambiente. Secretaria de Qualidade Ambiental: Plano Nacional de Resíduos Sólidos - 2020. Brasília: MMA/SQA, 2020. 187 p.

BRASIL. Ministério do Desenvolvimento Regional. Secretaria Nacional de Saneamento - SNS Sistema Nacional de Informações sobre Saneamento: Diagnóstico do Manejo de Resíduos Sólidos Urbanos - 2018. Brasília: SNS/MDR, 2019. 247.
BRASIL. Lei $\mathrm{n}^{\circ} 14.026$, de 15 de julho de 2020 Atualiza o marco legal do saneamento básico e altera a Lei $\mathrm{n}^{\circ}$ 9.984, de 17 de julho de 2000. Diário Oficial da União: Poder Legislativo. 135. ed. Brasília, DF, 16 jul. 2020. Seção 1, p. 1. Available in: https://www.in.gov.br/en/web/dou/-/lei-n-14.026-de15-de-julho-de-2020-267035421. Access in: 17 set. 2020a.

BRASIL. Ministério do Meio Ambiente. Redução de Emissões na disposição final. 2007. Available in: https://www.mma.gov.br/estruturas/srhu_urbano/pu blicacao/125 publicacao12032009023918.pdf. Access in: 17 set. 2020 c.

Cetrulo, T.B. et al. Effectiveness of solid waste policies in developing countries: A case study in Brazil. Journal of Cleaner Production, 2018. Available in: https://www.sciencedirect.com/science/article/pii/S09 59652618328142? casa_token=1YeY7DLhvF4AAAA A:9QPJW-

zW7JVbMM3M2VtPPDNIsqOODbnRHf1 ocL1Z8W yESWgzeyarTHXH1XdWGnqDsGdwLvE. Access in: 10 set. 2020.

Chen, X.; Geng, Y.; Fujita, T.. An overview of municipal solid waste management in China. Waste Management, v. 30, n. 4, p. 716-724, 2010. Available in: http://dx.doi.org/10.1016/j.wasman.2009.10.011. Access in 20 set. 2020.

COM. The role of energy waste in the circular economy. Commission communication to the European Parliament, the Council, the European Economic and Social Committee and the Committee of the Regions. Bruxelas, 26.1.2017. Available in: https://ec.europa.eu/environment/waste/waste-toenergy.pdf. Access in: 22 mai. 2020.

Consonni S, Silva P. Off-design performance of integrated waste-to-energy, combined cycle plants. Appl Therm Eng. 2007; volume 27:712e21.

Edo, M. et al. The combined effect of plastics and food waste accelerates the thermal decomposition of refuse-derived fuels and fuel blends. Fuel, [S.L.], v. 180, p. 424-432, set. 2016. Elsevier BV. http://dx.doi.org/10.1016/j.fuel.2016.04.062.

EMBRAPA. Production of briquettes and pellets from agricultural, agro-industrial and forestry residues. Brasília, 2012. Available in: https://ainfo.cnptia.embrapa.br/digital/bitstream/item/ 78690/1/DOC-13.pdf. Access in: 04 set. 2020.

ERFO. On recovered fuels and SRF, Available in https://erfo.info/about-srf, Access in 12 de november de 2020 .

Gallardo I., Antonio et al, 2020, Design of solid recovered fuels from municipal solid waste an $\mathrm{d}$ biomass. 24th International Congress on Project Management and Engineering Alcoi.

Garcés, D., Díaz, E., Sastre, H., Ordóñez, S., González-Lafuente, J. M., Evaluation of the potential of different high calorific waste fractions for the preparation of solid recovered fuels. Waste 
Management, [S.L.], v. 47, p. 164-173, jan. 2016. Elsevier http://dx.doi.org/10.1016/j.wasman.2015.08.029.

Garrido, M.A, Conesa, J.A, Garcia, M.D., 2017, Characterization and Production of Fuel Briquettes Made from Biomass and Plastic. Wastes Energies, vol. 10,850 .

Guerrini, A. et al., 2017, Assessing efficiency drivers in municipal solid waste collection services through a non-parametric method. Journal of Cleaner Production, v. 147, p. 431-441

Gug, J., Cacciola, D., Sobkowicz, M., 2015 , Processing and properties of a solid energy fuel from municipal solid waste (MSW) and recycled plastics. Waste Management, Vol. 35, pp. 283-292.

Greinert, A., Mrówczynska, M., Szefner, W. 2019, The Use of Waste Biomass from the Wood Industry and Municipal Sources for Energy Production. Sustainability. V11.

Hamid et al., 2020, Pelletization of RefuseDerived Fuel with Varying Compositions of Plastic, Paper, Organic and Wood. Sustainability.

IBGE (org.). Brazilian Indicators for Sustainable Development Goals: 2030. Agenda 2030. 2020. Available in: https://odsbrasil.gov.br. Access in: 10 set. 2020 .

IBGE - Notícias. Available in: https://agenciadenoticias.ibge.gov.br/agencianoticias/2012-agencia-de-noticias/noticias/27535desemprego-sobe-para-12-2-e-atinge-12-9-milhoesde-pessoas-no-1-trimestre. Access in 15 set. 2020.

IQBAL, M., Nadeem, A., \& Butt, M., 2019, Fuel pellets derived from municipal solid waste residues and rice husks. Bangladesh Journal of Scientific and Industrial Research, 54 (4), 329-338.

Infiesta et al. Design of an industrial solid waste processing line to produce refuse-derived fuel. J. Environ Manage. 2019. Available in: https:/www.sciencedirect.com/science/article/pii/S03 01479719301586 ? casa token $=$ oasIuLVHypAAAAA A:oNDebCbP0Vfn6E3ci0gqT-uJCdu7S4N5p5OZ41ZNKDguYc01RTa8vtygYyITGZQz ool4iI. Access in 16 set. 2020.

ISWA - International Solid Waste Association. The tragic case of dumpsites, 2015, Available in: https://www.iswa.org/fileadmin/galleries/Task Force s/THE_TRAGIC_CASE_OF_DUMPSITES.pdf Access in: 08 of march 2021 .

Jewiarz, M. et al., 2020, Parameters affecting RDF-based pellet quality. Energies, v. 13, n. 4, p. 910.

Kazimierz et al., 2020, Uso de resíduos em produção de pellets para fins energéticos. Renewable Energy. Elsevier, vol. 145 (C), pag. 997-1003.

Kyprianidis K. G. e Skvaril, 2016, Developments in Combustion Technology. InTechOpen. Londres, Reino Unido.

WEG. WEG offers the market a solution for generating electricity using Urban Solid Waste (RSU). 2019. Available in:
https://www.weg.net/institutional/BR/pt/news/produt os-e-solucoes/weg-oferece-ao-mercado-solucao-parageracao-de-energia-eletrica-com-utilizacao-deresiduos-solidos-urbanos-rsu. Access in 20.06.2020.

Lagerkvist, A., Dahlén, L., 2012, Solid Waste Generation and Characterization. Recovery Of Materials and Energy from Urban Wastes, [S.L.], p. 7-20. Springer New York. http://dx.doi.org/10.1007/978-1-4939-7850-2_110.

Lu, J., CHANG, Y., Poon, C., Lee, D., 2020, Slow pyrolysis of municipal solid waste (MSW): a review. Bioresource Technology, [S.L.], v. 312, p. 123615

http://dx.doi.org/10.1016/j.biortech.2020.123615.

Lee, D., LU, J., CHANG, J., 2020, Pyrolysis synergy of municipal solid waste (MSW): a review. Bioresource Technology, [S.L.], v. 318, p. 123912. http://dx.doi.org/10.1016/j.biortech.2020.123912.

Ma, W.; Hoffmann, G.; Schirmer, M.; Chen, G.; Rotter, V.S., 2010, Chlorine characterization and thermal behavior in MSW and RDF. J Hazard Mater, Vol. 178, pp. 489-498.

Mahajani, S. M., Arora, A., Pradhan, P., 2018, Production and utilization of fuel pellets from biomass: A review. Fuel Processing Technology, Vol. 181.

Malinauskaite J. et al. Management of municipal solid waste and energy waste in the context of a circular economy and energy recycling in Europe. Elsevier. Energia, Novembro de 2017. Available in: https://www.journals.elsevier.com/energy. Access in 20.05.2020.

Nouvion, P., A resilient waste management system to overcome the next crisis - ESWET. April de 2020.

Poma C, Verda V, Consonni S, 2010, Design and performance evaluation of a waste to- energy plant integrated with a combined cycle. Energy, Vol. 35:786e93.

Rezaei, H. et al., 2020, Pelletization of RefuseDerived Fuel with Varying Compositions of Plastic, Paper, Organic and Wood. Sustainability, Vol. 12, n. 11, p. 4645.

Rossi, C. R., Potential for Energy Recovery of Solid Urban Waste in the AMESC Region. Trabalho de Conclusão de Curso (graduação) - Universidade Federal de Santa Catarina. Campus Araranguá. Engenharia de Energia. 2014. Available in: https://repositorio.ufsc.br/handle/123456789/128062. Access in 18 set. 2020.

SNIS - Sistema Nacional De InformaçÕes Sobre Saneamento. Diagnosis of Water and Sewage Services - 2018. Ministério do Desenvolvimento Regional, Secretaria Nacional de Saneamento, Brasília, DF. 186 p. 2019.

Santa Catarina. Adenilso Biasus. Secretário de Estado do Desenvolvimento Econômico Sustentável. Santa Catarina state solid waste plan: administrative contract n. 012/2016. 2. ed. Florianópolis, 2018. 400 
p. (2). Available in: http://www.perssc.premiereng.com.br/documentos. Access in: 15 set. 2020.

Silva F., Valdemar, F. et al., 2019, Evaluation of gaseous emissions from thermal conversion of a mixture of solid municipal waste and wood chips in a pilot-scale heat generator. Renewable Energy, [S.L.], Vol. 141, p. 402-410. Available in: http://dx.doi.org/10.1016/j.renene.2019.04.032. Access in 03 set. 2020.

Soares, E. L. D. S. F., 2011,. Study of the Gravimetric Characterization and Calorific Power of Solid Urban Waste. Rio de Janeiro: UFRJ/COPPE.

Simões, P.; Marques, R. C., 2012, Performance evaluation of solid waste services in Portugal. Engenharia Sanitária e Ambiental, Available in: https://www.scielo.br/scielo.php?pid=S1413-

$41522009000200016 \&$ script $=$ sci_arttext\&tlng $=$ pt. Access in 10 set. 2020.

Song, B. et al., 2020, Producing a high heating value and weather resistant solid fuel via briquetting of blended wood residues and thermoplastics, Fuel. Vol. 283, p. 119263.

Souza, M. M., et al., 2020, Production and evaluation of pellets composed of different proportions of municipal solid waste. Nature and Conservation.

Sipra, A. T., Gao, N.; Sarwar, H., 2018, Municipal solid waste (MSW) pyrolysis for bio-fuel production: a review of effects of msw components and catalysts. Fuel Processing Technology, [S.L.], v. 175, p. 131-147. http://dx.doi.org/10.1016/j.fuproc.2018.02.012.

Srivastava, G. et al., 2014, Physicochemical and thermal characterization of nonedible oilseed residual waste as sustainable solid biofuel. Waste Management. Vol. 34.

Themelis, N. J., Bourtsalas, A. C. (Thanos), 2019, Recovery of Materials and Energy from Urban Wastes: encyclopedia of sustainability science and technology, second edition. 2. ed. New York: Springer 551 p. (3).

Themelis, N. J., Barriga, M. E. D., Estevez, P., Valesco, M. G., 2016, Guia Para Recuperar Energia E Materiais (Rem) De Resíduos Sólidos. Vitória: Wtert-brasil, p. 228, Tradução de Gustavo Queiroz de Souza. Available in: http://www.wtert.com.br. Access in: 17 Jul. 2020.

Tisi, Y. S. A B., 2019, Waste-To-Energy: energy recovery as an environmentally adequate way of disposing of urban solid waste. Brasília: Synergia, p.230.

Tumuluru et al., 2011, A review on Biomass Densification for Energy Applications. Conference Paper.

Vieira, K.S, 2019. Analysis of the efficiency of urban solid waste management in Brazil. Dissertação de Mestrado. Universidade Federal de Pernambuco, UFPE. Caruaru, Brasil, p. 103.
Virmond, E.; De Sena, R.F.; Albrecht, W.; Althoff, C.A.; Moreira, R.F.P.M.; José, H.J., 2012, Characterisation of agroindustrial solid residues as biofuels and potential application in thermochemical processes. Waste Management (Elmsford), Vol. 32, p. 1952-1961.

Vishwakarma, A; Kulshrestha, M; Kulshreshtha, M., 2015, Performance assessment of urban municipal solid waste management services in an Indian state. Journal of Solid Waste Technology and Management, Vol. 41, n. 3, p. 275-284. Available https://www.scopus.com/inward/record.uri?eid=2s2.084961324292\&partnerID $=40 \& \mathrm{md} 5=\mathrm{eb} 1581 \mathrm{~b} 13 \mathrm{dbb} 6$ effe60b760c4ee2ba9c. Access in 01 set. 2020.

ZKG. Recovered solid fuels - specifications and classes. Available in https://www.zkg.de/en/artikel/zkg_Solid_Recovered_ Fuels_Specifications_and_classes_2067874.html, acessado em 10 de novembro de 2020. 